Research paper

\title{
Compatibility analysis of municipal solid waste incineration residues and clay for producing lightweight aggregates
}

\author{
Margarida J. Quina ${ }^{\text {a, } *}$, Marisa A. Almeida ${ }^{b}$, Regina Santos ${ }^{b}$, João M. Bordado ${ }^{c}$, Rosa M. Quinta-Ferreira ${ }^{a}$

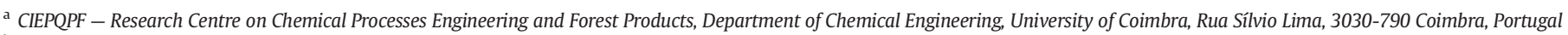 \\ b Centro Tecnológico da Cerâmica e do Vidro, Ap. 8052, 3020-053 Coimbra, Portugal \\ c Department of Chemical Engineering, Instituto Superior Técnico, Av. Rovisco Pais, 1049-001 Lisboa, Portugal
}

\section{A R T I C L E I N F O}

\section{Article history:}

Received 17 July 2013

Received in revised form 21 October 2014

Accepted 25 October 2014

Available online 10 November 2014

\section{Keywords:}

APC residues

MSW incineration

Lightweight aggregates

Recycling

Leaching

\begin{abstract}
A B S T R A C T
This work provides insight into the most important properties of air pollution control (APC) residues from municipal solid waste incineration (MSWI) and clay used at industrial level aiming at producing a ceramic material known as lightweight aggregates (LWA). Both clay and APC residues were characterized to assess the most important chemical, physical, thermal and mineralogical properties to evaluate their compatibility. The maximum percentage of incorporation tested was $10 \%$ of APC residues. The results showed that the waste does not own bloating properties and it is not expectable other improvements into the technological properties of LWA, since the fluxing components contribution is high and the amount of silica is low. Although during the thermal analysis of the APC residues the loss on weight is high (about $32 \%$ until $1200{ }^{\circ} \mathrm{C}$ ), they seem not to be suitable as a gas-release additive, once for $10 \%$ of incorporation the external shell appears to be significantly broken. The environmental impact due to leaching of pollutants from the LWA incorporating less than or equal to $5 \%$ of waste appears not to be relevant. In conclusion, the results showed that synthetic LWA may be considered as a possible approach to recycling of APC residues in case of low amount of waste is used or if a pre-treatment is performed.
\end{abstract}

(C) 2014 Elsevier B.V. All rights reserved.

\section{Introduction}

The municipal solid waste (MSW) incineration has been widely used in most of developed countries, as part of integrated management systems for their destruction and energy recovery. However, one of the important shortcomings of this process is the generation of hazardous air pollution control (APC) residues, which comprise particles captured in the flue gas cleaning system prior to discharge into the atmosphere (Chandler et al., 1997; Sabbas et al., 2003; Quina et al., 2008a). APC residues may represent $2-3 \%$ of the MSW incinerated, and thus a huge amount of these wastes have been landfilled in the world. These residues are produced at high-temperature, and therefore they are thermodynamically unstable and highly reactive under ambient conditions (Sabbas et al., 2003). In the literature there are various studies aimed at APC residues characterization, where properties such as moisture, loss on ignition (LOI), size distribution, density, porosity, specific surface area, morphology, total elemental content (TC), total availability (TA) and the leaching behavior, mineralogy and thermal behavior can be found (Chandler et al., 1997; Quina and Quinta-Ferreira, 2002; Quina et al., 2008b, 2009, 2011a, 2011b). The principal characteristics of concern are the high heavy metals content,

\footnotetext{
* Corresponding author. Tel.: +351 239798 700; fax: +351 239798703.

E-mail address: guida@eq.uc.pt (M.J. Quina).
}

soluble salts that leach in quantities that do not comply with the regulatory constraints, as well as the trace organic pollutants. Other studies analyze in particular the thermal behavior of such incinerator residues (Tettamanti et al., 1998; Wang et al., 1998; Sakai and Hiraoka, 2000; Mangialardi, 2001; Wang et al., 2002). A pre-treatment stage involving washing with water can be applied to APC residues in order to remove soluble salts prior to further utilization or chemical stabilization processes (Mangialardi, 2001; Nzihou and Sharrock, 2002; Sabbas et al., 2003). Salts may account for up to 10 to $20 \%$ of the material and are responsible for many of the negative effects of such residues. Some studies have indicated that a liquid-to-solid ratio of 10 allows for extraction of more than $90 \%$ of the soluble salts (mainly chlorides) (Nzihou and Sharrock, 2002). However, for evaluating the overall benefits of a washing pre-treatment, the shift of the pollutants from solid to liquid streams must be considered (Sabbas et al., 2003). Indeed, to assess the suitability for a specific application, besides the environmental impact, the ability for processing and the technical performance must be also considered (Ferreira et al., 2003).

In this framework, some European countries have devoted efforts to find feasible applications for APC residues rather than just disposed of in environmental acceptable landfills (Sabbas et al., 2003). Although these residues generally have limited applications, thermal treatments can produce a material that is environmentally stable, and may be further used for producing ceramics (Quina et al., 2008a). In this scope, 
the production of lightweight aggregates (LWA) has been considered for many secondary materials (Wainwright and Cresswell, 2001; Ducman et al., 2002; Cheeseman and Virdi, 2005; Cheeseman et al., 2005; Chiou et al., 2006; Quina et al., 2006; Huang et al., 2007; Qiao et al., 2008; Gonzalez-Corrochano et al., 2009, 2012; Chen et al., 2010; Kourti and Cheeseman, 2010; Latosinska and Zygadlo, 2011; Tan et al., 2012) such as combustion ashes, waste glass, sewage sludge ash, incinerator bottom ash, mining residues, heavy metal sludge, washing aggregate sludge, lignite coal fly ash, and contaminated mine soil. Indeed, LWA can be defined as materials lighter than water and more porous than sand, gravel or ground rock (commonly referred to as "dense" aggregates) and can be produced from natural resources (e.g. volcanic aggregates or pumice), requiring only mechanical treatment, or obtained by thermal processes in kilns (Chandra and Berntsson, 2002; de' Gennaro et al., 2004, 2005). In a broad sense, synthetic aggregates are ceramic materials obtained by thermal treatment of materials with expansive properties, such as (i) perlite, vermiculite, clay and shale and (ii) industrial by-products (e.g. fly ash, slags, and sludge) (Chandra and Berntsson, 2002). One of the most widespread types of LWA is produced from expanded clay and commercially known as Leca® (Lightweight Expanded Clay Aggregates), or from coal fly ash and referred as Lytag®. Expansion (bloating) occurs by heating materials to fusion temperature, where pyroplasticity and formation of gas must take place simultaneously. The technological applications of LWA are mostly linked to the low density and high compressive strength (de' Gennaro et al., 2005).

The valorization of fly ash and/or APC residues from MSW incineration in LWA has been analyzed only in few studies (Quina et al., 2006; Huang et al., 2007; Hwang et al., 2012; Tan et al., 2012). However, other sintered or melting materials and ceramic bricks have been considered (Wang et al., 1998; Sakai and Hiraoka, 2000; Mangialardi, 2001; Wang et al., 2002; Dimech et al., 2008; Haiying et al., 2011; Valle-Zermeño et al., 2013). Some studies point out that a washing treatment of APC residues with water to separate soluble salts may be important in the scope of their recycling (Mangialardi, 2001; Sabbas et al., 2003; Quina et al., 2011b), but attention should be given to the mobilization of toxic heavy metals (Nzihou and Sharrock, 2002). The stabilization of most heavy metals can be accomplished with chemical additives (Nzihou and Sharrock, 2002; Quina et al., 2010). It should be noted that an important benefit of recycling polluted wastes into synthetic aggregates is the low leachability usually observed (van der Sloot et al., 2001).

This work focuses on the characterization of APC residues from MSW incineration and natural clay currently used in industry in order to assess the possibility of producing lightweight aggregates.

\section{Materials and methods}

\subsection{Characterization of APC residues and natural clay}

In our study, APC residues samples were collected in an incineration plant in the region of Lisbon, comprising gas cleaning residues from economizer, semi-dry scrubbers (with lime and activated carbon) and fabric filters; the sample of natural clay was taken in an industry that produces LWA in the center region of Portugal. APC residues were extensively characterized in our previous study (Quina et al., 2008b), where moisture content, loss on ignition (LOI), particle size distribution, density, porosity, specific surface area, morphology, total elemental content (TC), total availability (TA), leaching behavior with common compliance tests, and the acid neutralization capacity (ANC) can be found. The main mineralogical crystalline phases were identified, and the thermal behavior of the APC residues is also shown. Those parameters were determined for 5 different samples, collected over two years. The specific features of the leaching behavior of these residues may be found in other publications (Quina et al., 2009, 2010, 2011a, 2011b). In the present study, the analysis of the thermal behavior was deepened for one sample (referred as A2), aiming at considering the recycling of the waste by its incorporation in LWA, and includes simultaneous thermal analysis (STA), X-ray diffraction (XRD) and heating microscopy.

The natural clay was characterized regarding moisture content through weight loss over night in an oven at $105^{\circ} \mathrm{C}$; loss on ignition (LOI) was determined as the weight loss after exposing the clay at $1000{ }^{\circ} \mathrm{C}$ using a muffle furnace during $1 \mathrm{~h}$; the real specific density was determined by using helium pycnometry, Micromeritics-AccuPyc 1330, based on the amount of displaced gas (helium); the total dissolved solids (TDS), $\mathrm{pH}$ and electrical conductivity were determined in the liquid obtained at liquid-to-solid ratio (L/S) of $10 \mathrm{~mL} / \mathrm{g}$, under agitation for $24 \mathrm{~h}$ with demineralised water; the particle size distribution was determined by sedimentation, Micromeritics-SediGraph 5100. In addition, the elemental composition of clay was assessed using X-ray fluorescence (XRF), Philips-PW 1480, equipped with an $\mathrm{Rh} \mathrm{X}$-ray tube. The samples were dried, finely grinded and mixed with $\mathrm{Li}_{2} \mathrm{~B}_{4} \mathrm{O}_{7}$ (66.5\%) and $\mathrm{LiBO}_{2}$ (33.5\%). The major elements were reported as wt.\% oxide. Powder XRD, Philips-PW 1710, with $\mathrm{Cu} \mathrm{K \alpha}$ radiation (40 kV and $30 \mathrm{~mA}$ ) was also employed and the minerals were recognized according to the data base ICDD (International Centre for Diffraction Data).

The thermal behavior of both clay and APC residues was obtained by using STA, Netzsch - STA 449C, with a heating rate of $10{ }^{\circ} \mathrm{C} / \mathrm{min}$ in air. This test allowed us to obtain simultaneously the thermogravimetric analysis (TGA) and differential scanning calorimetry (DSC) of samples previously milled to less than $75 \mu \mathrm{m}$, using about $20-30 \mathrm{mg}$ of powder. Heating microscopy, Leitz-2A, enabled us to observe with video recording $3 \mathrm{~mm}$ sided cubic samples of clay and APC residues by heating them to $1500{ }^{\circ} \mathrm{C}$ at a rate of $10{ }^{\circ} \mathrm{C} / \mathrm{min}$.

The total content (TC) of previously calcined APC residues at $1100{ }^{\circ} \mathrm{C}$ for $1 \mathrm{~h}$ was determined by acid digestion with aqua regia, using $3 \mathrm{~mL}$ of $\mathrm{HNO}_{3}(65 \%)$ and $10 \mathrm{~mL}$ of $\mathrm{HCl}(38 \%)$ in a digestion bomb (Parr 4744). The solid sample $(0.4 \mathrm{~g})$ and the acid mixture $(13 \mathrm{~mL})$ within the bomb were heated in a conventional oven during $6 \mathrm{~h}$ at $150{ }^{\circ} \mathrm{C}$. These analyses were carried out in triplicate.

\subsection{Washing of APC residues}

The washing treatment of APC residues involved extractions with water in one or two stages, at $\mathrm{L} / \mathrm{S}$ of $10 \mathrm{~mL} / \mathrm{g}$, using an open beaker under agitation through a magnetic stirrer at $120 \mathrm{rpm}$. The separation of both phases was conducted by vacuum filtration through a $0.45 \mu \mathrm{m}$ membrane filter. The solid and liquid phases were collected and preserved for further chemical analysis. The times of extractions were $0.5,1,5,10,30,60,480 \mathrm{~min}$ and $24 \mathrm{~h}$. In the washing solutions $\mathrm{pH}$, electrical conductivity (EC), total dissolved solids (TDS), concentration of the soluble ions $\left(\mathrm{Cl}^{-}, \mathrm{Na}^{+}, \mathrm{K}^{+}\right)$and toxic heavy metals ( $\mathrm{Pb}, \mathrm{Zn}, \mathrm{Cr}$ ) were measured. The flame atomic absorption spectrometry (FAAS), Perkin Elmer-3300, and ion chromatography, Waters-Action Analyzer, were used as the main analytical techniques.

Moreover, some experiments were conducted by adding a small amount of phosphoric acid, in order to reduce the mobilization of toxic heavy metals (mainly $\mathrm{Pb}$ which is the most critical element). The experimental conditions involved $248.5 \mathrm{~mL}$ of water plus $1.5 \mathrm{~mL}$ of $\mathrm{H}_{3} \mathrm{PO}_{4}(85 \%)$ and $25 \mathrm{~g}$ of APC residues, which means a L/S of $10 \mathrm{~L} / \mathrm{kg}$ for $10 \mathrm{~min}$.

\subsection{Preparation and characterization of LWA}

The LWA were produced not only using natural raw materials but also incorporating APC residues, according to the formulations shown in Table 1. The LWA were prepared and sintered based on the method used for quality control in the laboratory of the industrial plant that produces commercial LWA. The experimental procedure to obtain LWA followed different phases: homogenisation of clay and APC residues during $30 \mathrm{~min}$; blend the mixture by adding about $20 \%$ of water and $1 \%$ of oil (as expanding agent) to achieve sound pelletization 
Table 1

Formulations tested and firing conditions used to produce lightweight aggregates

\begin{tabular}{lccl}
\hline Formulation & APC residues (\%) & Clay $(\%)$ & Firing conditions \\
\hline LA0 & 0 & 100 & 8 min at $1100{ }^{\circ} \mathrm{C}$ \\
LA1 & 1 & 99 & 8 min at $1100{ }^{\circ} \mathrm{C}$ \\
LA5 & 5 & 95 & 8 min at $1100{ }^{\circ} \mathrm{C}$ \\
LA10 & 10 & 90 & 8 min at $1070{ }^{\circ} \mathrm{C}$ \\
\hline
\end{tabular}

in a mechanical device; the pellets were first dried at 110 and $200{ }^{\circ} \mathrm{C}$ for $2 \mathrm{~h}$, and then fired in a muffle furnace over $\mathrm{CaCO}_{3}$ at 1100 or $1070{ }^{\circ} \mathrm{C}$ for $8 \mathrm{~min}$ to obtain a glassy material. The formulation LA10 requires lower temperature $\left(1070{ }^{\circ} \mathrm{C}\right)$ otherwise it disintegrates during the firing process.

The bulk density was determined by weighing the mass of $1 \mathrm{~L}$ of aggregates, and the density of particles was assessed by displacement of mercury. The mechanical strength was measured according to DIN 4226-Part 3, using a specific press (Tecnilab LST) for applying a pressure to a container with $1 \mathrm{~L}$ of LWA during $100 \mathrm{~s}$.

In addition, to evaluate the potential environmental impact of LWA to soil and water, the classic standards DIN 38414-S4 (leaching for $24 \mathrm{~h}$ in agitation, at L/S equal 10) and TCLP (leaching test with acetic acid solution $\mathrm{pH} 2.88$ and $\mathrm{L} / \mathrm{S} 20$, over $18 \mathrm{~h}$ ) were used. In both leaching tests, the LWA were milled up to $1 \mathrm{~mm}$, with a hammer mill. The metals $\mathrm{Pb}, \mathrm{Cd}, \mathrm{Cr}$, Ni and $\mathrm{Cu}$ were quantified through graphite furnace atomic absorption spectrometry (GFAAS), Perkin Elmer-AAnalyst 600, Zn by flame atomic absorption spectrometry (FAAS), Perkin Elmer-3300. The anions $\mathrm{Cl}^{-}$and $\mathrm{SO}_{4}^{2-}$ were measured by ion chromatography, WatersAction Analyzer, and $\mathrm{F}^{-}$by potentiometry.

\section{Results and discussion}

\subsection{Characterization of natural clay}

The natural clay considered in our study has been used in industry for producing LWA of expanded clay. Table 2 summarizes some of the properties of the clay, such as moisture content (MC), loss on ignition (LOI) and real specific density $\left(\rho_{\mathrm{r}}\right)$. In addition, certain properties were measured in eluates obtained by leaching clay at L/S of 10:1 and under agitation for $24 \mathrm{~h}$. As expected, the values determined in the eluate for EC, TDS and metal concentrations are low, since the clay was stored next to the industrial plant, in a stockpile for aging for 2 to 3 months under weather conditions (rain, wind, sun, etc.). At industrial level, it is well known that this aging period improves the technological properties when compared with freshly-mined clay.

The particle size distribution determined by sedimentation showed that the clay comprises $36.3 \%$ of clay fraction $(<2 \mu \mathrm{m}), 56.7 \%$ of silt $(2-63 \mu \mathrm{m})$ and $7.1 \%$ of sand fraction $(>63 \mu \mathrm{m})$.

The analysis of major elements of natural clay using XRF revealed the chemical composition indicated in Table 3. Thus, the requirement for bloating materials indicated in the literature (Riley, 1951; de' Gennaro et al., 2004; Chiou et al., 2006; Gonzalez-Corrochano et al., 2009; Latosinska and Zygadlo, 2011) is observed for clay since $\mathrm{SiO}_{2}: 48-70 \%$, $\mathrm{Al}_{2} \mathrm{O}_{3}: 8-25 \%$ and fluxing oxides $\left(\mathrm{Fe}_{2} \mathrm{O}_{3}+\mathrm{CaO}+\mathrm{MgO}+\mathrm{Na}_{2} \mathrm{O}+\mathrm{K}_{2} \mathrm{O}\right)$ 4.5-31\%. Indeed, Fig. 1 shows that by plotting the normalized composition of the clay in the ternary diagram $\mathrm{SiO}_{2}-\mathrm{Al}_{2} \mathrm{O}_{3}$-fluxing, it is within the bloating area established by Riley (1951). Therefore, enough viscous phases are expected during the sintering of LWA for trapping gas released. For comparison purposes, Table 3 includes also data from the literature (Chiou et al., 2006; Latosinska and Zygadlo, 2011, termed as [C1] and [C2], respectively) and in general close values were observed mainly for $\mathrm{SiO}_{2}$ and $\mathrm{Al}_{2} \mathrm{O}_{3}$. The clay characterized by Latosinska and Zygadlo (2011) comprises lower content of $\mathrm{Fe}_{2} \mathrm{O}_{3}$ and fluxing, but it is still recommended for bloating materials.

Moreover, major ( $\mathrm{Si}, \mathrm{Al}$, Fe and $\mathrm{K}$ ) and minor (Mg, P, S, Ba, Sr, Rb, Zn, $\mathrm{Cu}, \mathrm{Ni}, \mathrm{Ti}, \mathrm{Ca}, \mathrm{Cd}$ and $\mathrm{Mn}$ ) elements were detected by XRF in clay. It must be noticed that sodium and chloride were not identified in this analysis.

Crystalline phases present in the clay were determined by XRD and the spectrum is shown in Fig. 2. The data point out that quartz $\left(\mathrm{SiO}_{2}\right)$ and illite $\left(\left(\mathrm{K}, \mathrm{H}_{3} \mathrm{O}\right)(\mathrm{Al}, \mathrm{Mg}, \mathrm{Fe})_{2}(\mathrm{Si}, \mathrm{Al})_{4} \mathrm{O}_{10}\right)$ are the major crystalline phases present together with some hematite $\left(\mathrm{Fe}_{2} \mathrm{O}_{3}\right)$, smectite $((\mathrm{Na}$, $\left.\left.\mathrm{Ca}_{0.5}\right)_{0.3}\left((\mathrm{Al}, \mathrm{Fe}, \mathrm{Mg})_{2}(\mathrm{Si}, \mathrm{Al})_{4} \mathrm{O}_{10}\right)(\mathrm{OH})_{2} \cdot \mathrm{nH}_{2} \mathrm{O}\right), \quad$ kaolinite $\left(\mathrm{Al}_{4} \mathrm{Si}_{4} \mathrm{O}_{10}(\mathrm{OH})_{8}\right)$ and traces of feldspar $\left((\mathrm{Na}, \mathrm{K}) \mathrm{AlSi}_{3} \mathrm{O}_{8}\right)$ and calcite $\left(\mathrm{CaCO}_{3}\right)$. Although the XRD analysis was carried out qualitatively, by taking into account the intensity of peaks at a five star rating, quartz $\left({ }^{* * *}\right)$ and illite $\left(^{* * *}\right)$ are the most significant crystalline phases, and kaolinite, smectite and hematite $\left(^{*}\right)$ were detected in minor amounts. In fact, according to the literature (Konta, 1995; de' Gennaro et al., 2004; Latosinska and Zygadlo, 2011) the main minerals of expanding clays are variable amounts of quartz, illite, smectite, kaolinite and numerous accessory minerals. Increasing amounts of kaolinite and mica do not favor the production of LWA (Konta, 1995).

The thermogravimetric behavior of the clay, Fig. 3, was analyzed by STA between 20 and $1200{ }^{\circ} \mathrm{C}$ yielding a total weight loss of 8.6\%, which is the result of two main contributions: $3.1 \%$ till $330{ }^{\circ} \mathrm{C}$ and $4.9 \%$ up to about $850{ }^{\circ} \mathrm{C}$. The initial reactions are predominantly endothermic (DSC curve) due to the loss of free water and the exothermic reactions were observed probably due to the oxidation of organic matter. The mass loss observed to around $850{ }^{\circ} \mathrm{C}$ probably resulted from carbonate minerals decomposition. In the last phase of the thermogram (higher than $850{ }^{\circ} \mathrm{C}$ ) a low weight loss of $0.6 \%$ and a significant heat absorption by the sample are observed. In the literature, few studies were found concerning TGA analysis of such clays. Chen et al. (2012) analyzed sediments with a similar composition to the clay and the thermogravimetric behavior revealed a global weight loss of about 7\%. In Fig. 3 the results observed for the residue and for a mixture of both are also indicated, but these data will be discussed in the next section.

Some heating microscope images of a cubic clay sample, during sintering at a heating rate of $10{ }^{\circ} \mathrm{C} / \mathrm{min}$ are shown in Fig. 4, where the dimensional changes of the sample can be detected by comparing the silhouette captured from 40 to $1362{ }^{\circ} \mathrm{C}$. Until $927^{\circ} \mathrm{C}$ the reduction of the sample dimensions was almost undetectable, and thus this may be considered the initial sintering temperature. This marks the beginning of changes to the phase state in the structure of the sintered material (Latosinska and Zygadlo, 2011). The final sintering temperature is about $1200{ }^{\circ} \mathrm{C}$, and at $1224{ }^{\circ} \mathrm{C}$ the softening phenomenon is perceptible. The maximum expanded temperature occurs at $1300{ }^{\circ} \mathrm{C}$, where the image of the sample achieved the largest area in the projection on the field. By increasing the temperature further, the sample becomes softer and viscosity significantly decreases until $1362{ }^{\circ} \mathrm{C}$, where the sample is

Table 2

Properties of the clay and APC residues (metal and $\mathrm{Cl}^{-}$concentrations in $\mathrm{mg} / \mathrm{kg}$ ).

\begin{tabular}{|c|c|c|c|c|c|c|c|c|c|c|c|c|c|c|c|}
\hline & \multirow[t]{2}{*}{ MC (\%) } & \multirow[t]{2}{*}{ LOI $(\%)$} & \multirow[t]{2}{*}{$\rho_{\mathrm{r}}\left(\mathrm{g} / \mathrm{cm}^{3}\right)$} & \multicolumn{12}{|c|}{ Measured in the eluate $(\mathrm{L} / \mathrm{S}=10$ ) } \\
\hline & & & & $\mathrm{pH}$ & $\mathrm{EC}(\mathrm{ms} / \mathrm{cm})$ & TDS (g/kg) & $\mathrm{Pb}$ & $\mathrm{Cr}$ & $\mathrm{Cu}$ & $\mathrm{Ni}$ & $\mathrm{Cd}$ & $\mathrm{Zn}$ & $\mathrm{Ca}$ & K & $\mathrm{Cl}^{-}$ \\
\hline Clay & 15 & 6.6 & 2.66 & 8.49 & 0.346 & 2.65 & $<0.9$ & $<1.17$ & $<0.9$ & $<1.45$ & $<0.07$ & 0.23 & 749 & 104 & nd \\
\hline $\mathrm{APC}_{\text {residues }}$ & 0.85 & $8.3^{\mathrm{a}}$ & 2.52 & 12.5 & 37.5 & 222 & 324 & 5.97 & 1.38 & 2.54 & 0.15 & 50.5 & 40,900 & 26,600 & 98,400 \\
\hline
\end{tabular}

nd - not determined.

a Determined at $750{ }^{\circ} \mathrm{C}$. 
Table 3

Chemical composition of clay (through XRF) and APC residues (\% w/w).

\begin{tabular}{|c|c|c|c|c|c|c|c|c|c|c|c|c|}
\hline Ref. & $\mathrm{SiO}_{2}$ & $\mathrm{Al}_{2} \mathrm{O}_{3}$ & $\mathrm{Fe}_{2} \mathrm{O}_{3}$ & $\mathrm{CaO}$ & $\mathrm{MgO}$ & $\mathrm{Na}_{2} \mathrm{O}$ & $\mathrm{K}_{2} \mathrm{O}$ & $\Sigma F^{a}$ & $\mathrm{Ti}_{2} \mathrm{O}$ & $\mathrm{MnO}$ & $\mathrm{P}_{2} \mathrm{O}_{5}$ & LOI \\
\hline Clay_our study & 55.4 & 18.2 & 8.0 & 1.9 & 3.9 & $<0.5$ & 4.3 & $18.1-18.6$ & 0.9 & 0.11 & $<0.5$ & 6.8 \\
\hline [C1] & 62.8 & 16.8 & 7.0 & 1.0 & 2.3 & 1.7 & 3.1 & 15.1 & ni & ni & ni & ni \\
\hline [C2] & 68.1 & 15.2 & 4.3 & 0.74 & 1.05 & 0.4 & 1.9 & 8.4 & 0.77 & 0.015 & ni & 7.1 \\
\hline \multicolumn{13}{|l|}{ APC residues } \\
\hline $\mathrm{A} 2$ & 14.1 & 7.4 & 2.3 & 41.9 & 1.0 & 3.7 & 3.2 & 52.1 & nd & nd & nd & $8.3^{\mathrm{b}}$ \\
\hline A2_1st_extr. & 18.7 & 9.8 & 3.1 & 36.2 & 2.2 & 1.3 & 0.8 & 43.5 & nd & nd & nd & nd \\
\hline A2_2nd_extr. & 26.1 & 10.3 & 4.3 & 33.3 & 2.3 & 0.3 & $<\mathrm{DL}$ & 40.2 & nd & nd & nd & nd \\
\hline
\end{tabular}

[C1] - Chiou et al., 2006; [C2] - Latosinska and Zygadlo, 2011; ni - not indicated; nd - not determined; DL - detection limit.

a $\mathrm{E} F=$ Fluxing oxides $=\mathrm{Fe}_{2} \mathrm{O}_{3}+\mathrm{CaO}+\mathrm{MgO}+\mathrm{Na}_{2} \mathrm{O}+\mathrm{K}_{2} \mathrm{O}$

b Determined at $750{ }^{\circ} \mathrm{C}$.

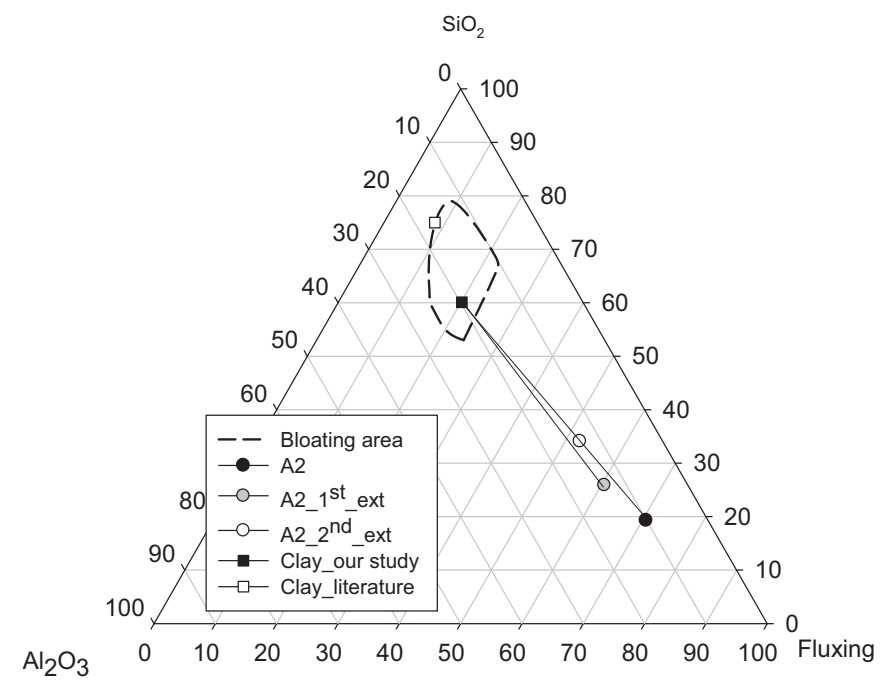

Fig. 1. Composition of clay of our study and from the literature (Latosinska and Zygadlo, 2011), as well as APC residues as received (A2) after one extraction (A2_1st_ex.) and after two extractions (A2_2nd_ext).

completely melted, and this may be considered the fluxing temperature. Similar measurements were reported in the literature (de' Gennaro et al., 2005; Latosinska and Zygadlo, 2011) for clay and Neapolitan yellow tuff, respectively, aiming at producing lightweight aggregates. It is important to notice that these results were obtained at a heating rate of $10{ }^{\circ} \mathrm{C} / \mathrm{min}$, and thus the sintering and bloating processes which occur in the industrial kiln will be different. Indeed, the industry that uses the same clay produces LWA at a maximum kiln temperature of $1170{ }^{\circ} \mathrm{C}$.

\subsection{Characterization of APC residues before and after washing}

As mentioned previously, APC residues were extensively characterized in our former studies (Quina and Quinta-Ferreira, 2002; Quina et al., 2008b, 2009, 2010, 2011a,b). Nevertheless, Table 2 summarizes the same properties as the ones reported for clay for comparison purposes, and the differences are rather clear. Indeed, contrarily to the results observed to clay, the values of EC, TDS and metals determined in leaching solutions with water were high. In particular, the leaching of $\mathrm{Pb}$ exceeds the environmental criteria even for disposal of this material in hazardous landfills. Therefore, one important point of this research will be the evaluation of the possible immobilization of heavy metals into the ceramic matrix. The particle size distribution of APC residues diameters was between 0.001 and $1 \mathrm{~mm}$ being characterized by a mean diameter of $124 \mu \mathrm{m}$ and a median of $86 \mu \mathrm{m}$ (Quina et al., 2008b). This waste was also analyzed through XRF, which allowed the identification of about 20 different elements: $\mathrm{Ca}, \mathrm{Cl}, \mathrm{K}$ and $\mathrm{S}$ as major elements; Fe, Cr, Ti, P, Si, Al, Mg, Na, Cu, Zn, Ba, Sn, Sb, Sr, Br and Pb as minor. However, given that XRF analysis was only qualitative, the oxide composition was calculated based on the total elemental content (of sample with reference A2), determined by acid digestion (Quina et al., 2008b), and the values obtained are indicated in Table 3. These records were also represented in the Riley diagram in Fig. 1, after normalization to $100 \%$, where it is observed that the composition is far from the bloating area. Therefore, for recycling APC residues into LWA, the use of a bloating material is essential, otherwise the material expansion will not occur. Also other studies (Chen et al., 2010) showed that MSW incineration APC residues were not within the limits of the bloating region of the ternary diagram (Riley diagram), due to the low content of $\mathrm{SiO}_{2}$. Hence, the sintering at high temperature does not afford a liquid phase with enough viscosity. On the other hand, these residues had high $\mathrm{CaO}$ content (>30\%), while the preferred content

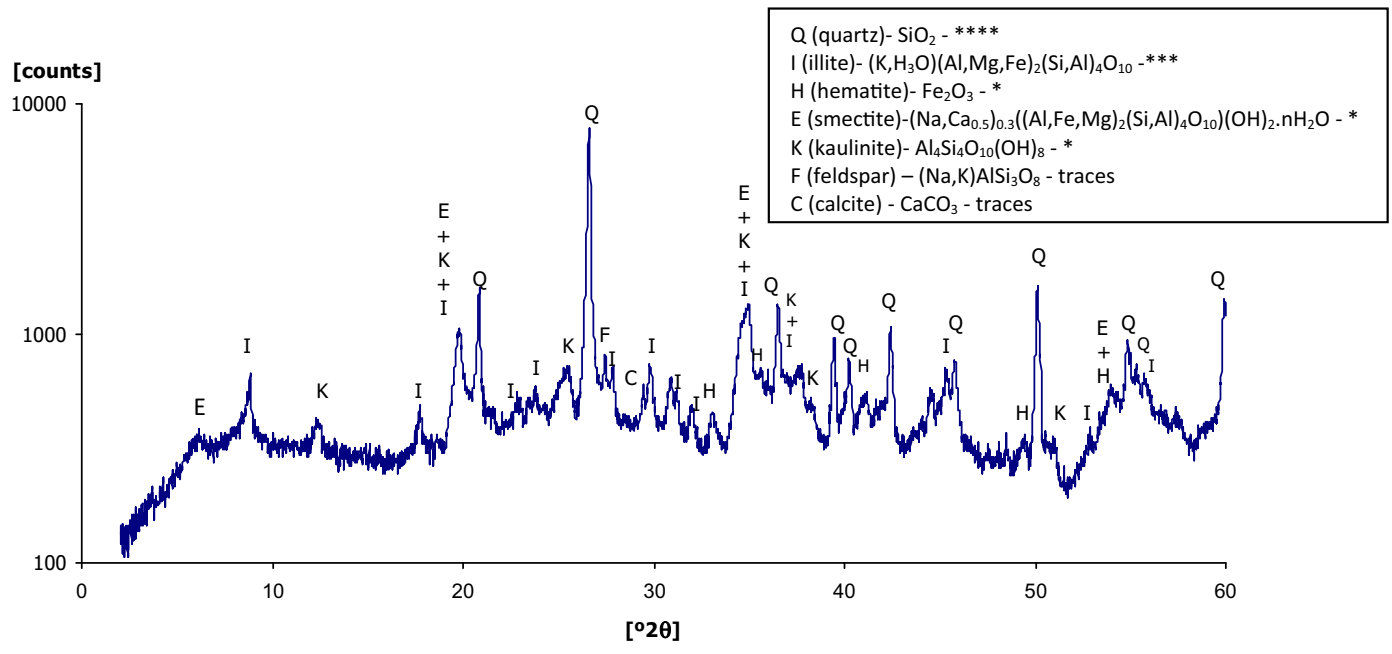

Fig. 2. XRD diagram for natural clay. 


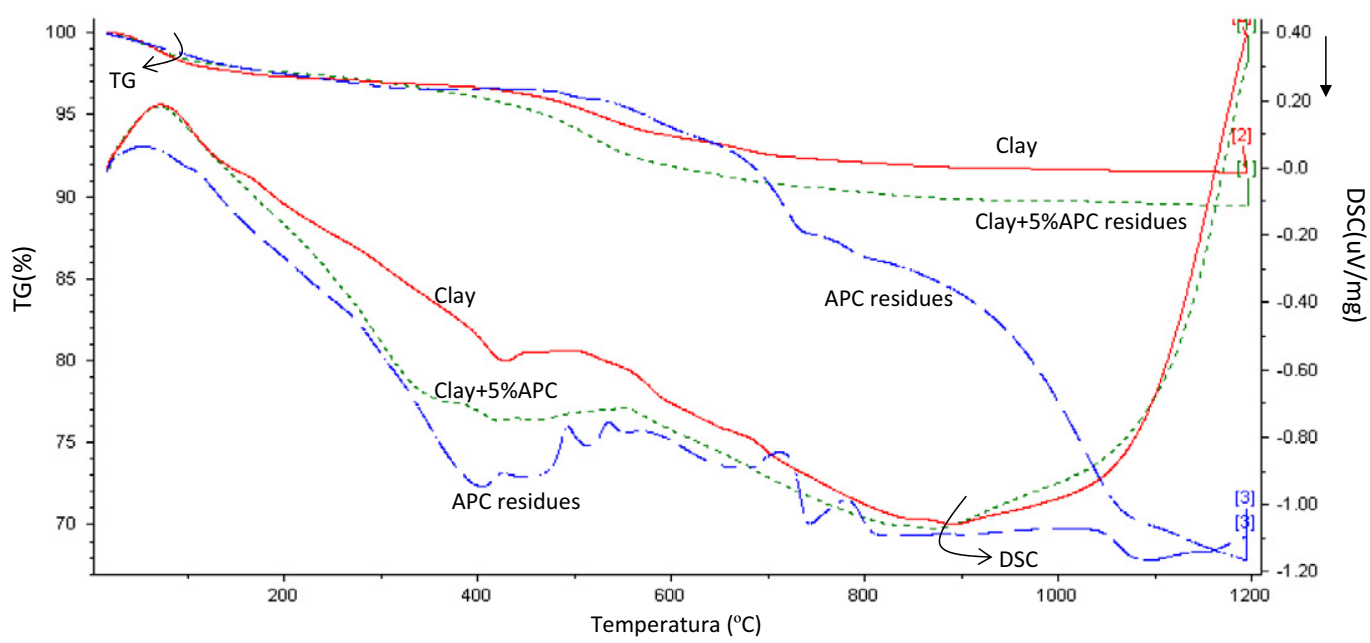

Fig. 3. Simultaneous thermal analysis (STA) of the clay (-), APC residues (-.- ) and a mixture of both (- -).

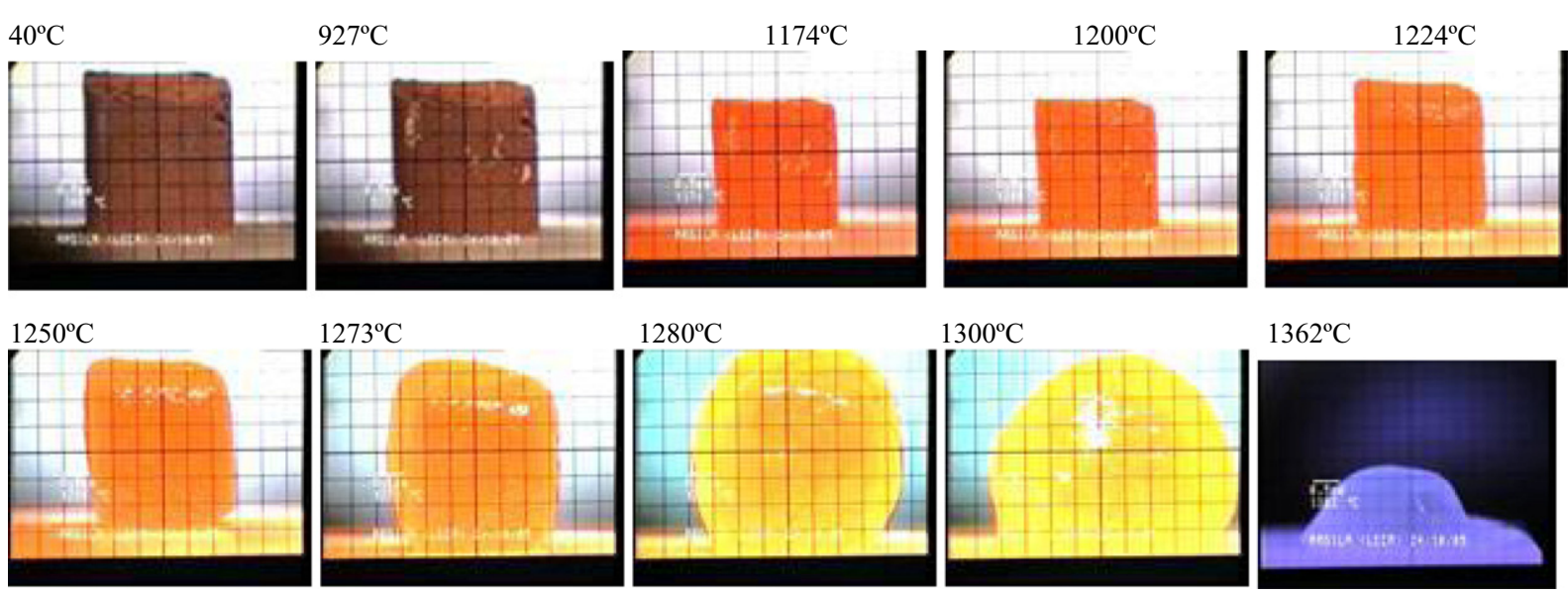

Fig. 4. Heating microscopy images of a cubic clay sample $(3 \times 3 \times 3 \mathrm{~mm})$ at different characteristic temperatures during sintering up to $1362{ }^{\circ} \mathrm{C}$ with heating rate $10{ }^{\circ} \mathrm{C} / \mathrm{min}$.

$(\mathrm{CaO}+\mathrm{MgO})$ is normally not more than $7 \%$. Similarly, by normalizing for $100 \%$ the data of the chemical composition determined by XRF for similar residues, Dimech et al. (2008) found a fluxing, $\mathrm{SiO}_{2}$ and $\mathrm{Al}_{2} \mathrm{O}_{3}$ of $82.6,12.5$ and $4.9 \%$, respectively; after washing the APC residues those values were changed for 77.3, 15.0 and $7.7 \%$. By contrast, in our previous study (Quina et al., 2006) it was shown that there are wastes, such as coal fly ashes, with bloating properties which allow in some cases their direct use for producing LWA.

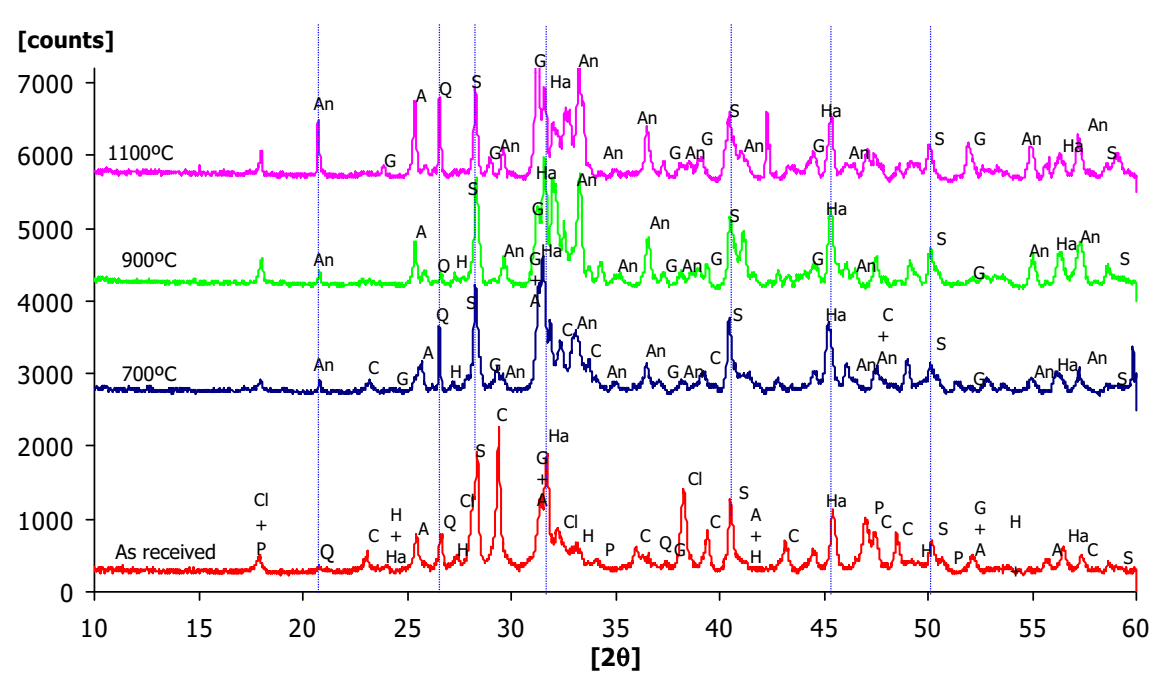

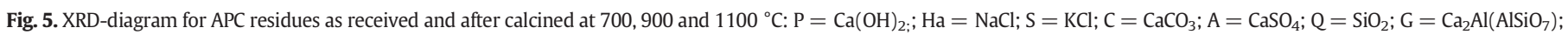
$\left.\mathrm{Cl}=\mathrm{Ca}(\mathrm{OH}) \mathrm{Cl} ; \mathrm{H}=\mathrm{Fe}_{2} \mathrm{O}_{3} ; \mathrm{An}=\mathrm{Ca}_{3} \mathrm{Fe}_{2}\left(\mathrm{SiO}_{4}\right)_{3}\right)$. 
Table 4

Total elemental content and leaching behavior of APC residues $(\mathrm{mg} / \mathrm{kg})$, before and after calcination.

\begin{tabular}{|c|c|c|c|c|c|c|c|c|c|c|c|c|}
\hline \multirow[t]{2}{*}{ Sample } & \multicolumn{6}{|c|}{ Total content } & \multicolumn{6}{|c|}{ Leaching with water, at $\mathrm{L} / \mathrm{S}=10$ for $24 \mathrm{~h}$} \\
\hline & $\mathrm{Pb}$ & $\mathrm{Cd}$ & $\mathrm{Zn}$ & $\mathrm{Cr}$ & $\mathrm{Ni}$ & $\mathrm{Cu}$ & $\mathrm{Pb}$ & $\mathrm{Cd}$ & $\mathrm{Zn}$ & $\mathrm{Cr}$ & $\mathrm{Ni}$ & $\mathrm{Cu}$ \\
\hline A2 & 2020 & 64 & 4308 & 232 & 121 & 456 & 353 & $<0.2$ & 28 & 6.9 & $<1.5$ & $<0.9$ \\
\hline A2 calc_ $1100{ }^{\circ} \mathrm{C}$ & 212 & 1.9 & 3042 & 348 & 117 & 428 & $<0.9$ & $<0.2$ & $<0.2$ & 66 & $<1.45$ & $<0.9$ \\
\hline $\mathrm{RL}^{\mathrm{a}}$ & & & & & & & 20 & 5 & 100 & 5 & 20 & 100 \\
\hline
\end{tabular}

a Regulatory limit for hazardous waste landfills.

$40^{\circ} \mathrm{C}$

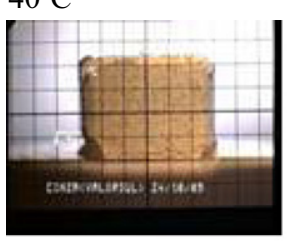

$1415^{\circ} \mathrm{C}$

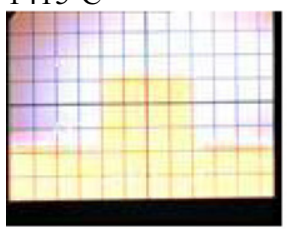

$1251^{\circ} \mathrm{C}$

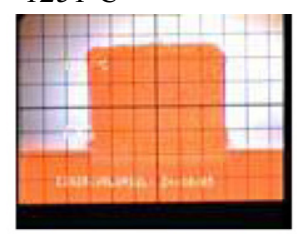

$1474^{\circ} \mathrm{C}$

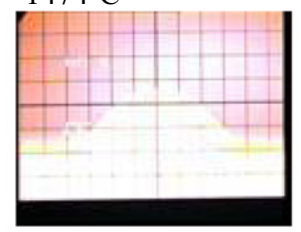

$1300^{\circ} \mathrm{C}$

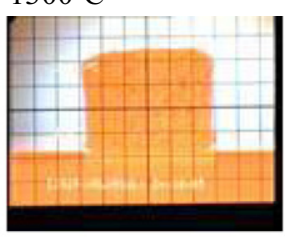

$1488^{\circ} \mathrm{C}$

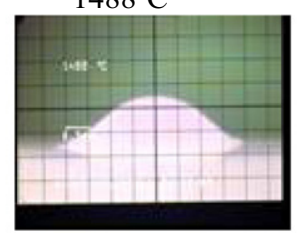

$1400^{\circ} \mathrm{C}$

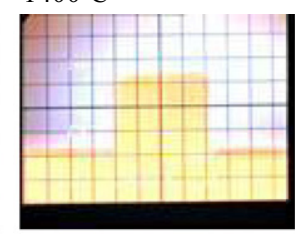

$1500^{\circ} \mathrm{C}$

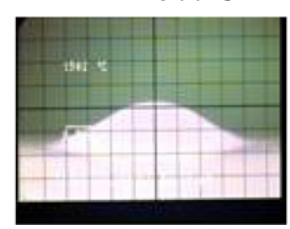

Fig. 6. Heating microscopy images of a cubic APC residues sample $(3 \times 3 \times 3 \mathrm{~mm})$ at different temperatures up to $1500{ }^{\circ} \mathrm{C}$ with heating rate $10{ }^{\circ} \mathrm{C} / \mathrm{min}$.

Moreover, crystalline phases present in the APC residues were determined by XRD, for the sample as received and after calcined at 700, 900 and $1100{ }^{\circ} \mathrm{C}$, Fig. 5. Initially the main phases identified were halite $(\mathrm{NaCl})$, sylvite $(\mathrm{KCl})$, calcite $\left(\mathrm{CaCO}_{3}\right)$, anhydrite $\left(\mathrm{CaSO}_{4}\right)$, quartz $\left(\mathrm{SiO}_{2}\right)$, gehlenite $\left(\mathrm{Ca}_{2} \mathrm{Al}\left(\mathrm{AlSiO}_{7}\right)\right)$, hematite $\left(\mathrm{Fe}_{2} \mathrm{O}_{3}\right)$, portlandite $\left(\mathrm{Ca}(\mathrm{OH})_{2}\right)$ and calcium hydroxychloride $(\mathrm{Ca}(\mathrm{OH}) \mathrm{Cl})$. Most of these phases were identified in other studies as well (Dimech et al., 2008). The interpretation of the spectra after calcination is not easy, since solid phases may suffer only slight rearrangements which can originate distinct peaks. Nevertheless, it can be concluded that $\mathrm{SiO}_{2}, \mathrm{KCl}, \mathrm{NaCl}, \mathrm{CaSO}_{4}$ and $\mathrm{Ca}_{2} \mathrm{Al}\left(\mathrm{AlSiO}_{7}\right)$ are stable for all temperatures; $\mathrm{CaCO}_{3}$ was identified at $700{ }^{\circ} \mathrm{C}$ but not at 900 and $1100{ }^{\circ} \mathrm{C} ; \mathrm{Ca}(\mathrm{OH})_{2}$ and $\mathrm{Ca}(\mathrm{OH}) \mathrm{Cl}$ were not identified at any of the calcination temperatures; $\mathrm{Fe}_{2} \mathrm{O}_{3}$ was not observed at any of the calcination temperatures but probably a new phase andradite $\left(\mathrm{Ca}_{3} \mathrm{Fe}_{2}\left(\mathrm{SiO}_{2}\right)_{3}\right)$ emerged, which is characterized by a greenish-gray color and thus it may be responsible for the appearance of the residue after calcination. Although the $\mathrm{CaO}$ is a product of thermal decomposition of the phases of calcium, this mineral was not identified in the XRD spectra, probably due to its high reactivity, and thus it tends to react with the phases of silicon, aluminium and iron.

The total elemental content of the calcined residue at $1100{ }^{\circ} \mathrm{C}$ concerning the toxic heavy metals are reported in Table 4, and during this thermal treatment about $14.6 \%$ of the global mass was lost due to decomposition of mineral phases (e.g. $\mathrm{Ca}(\mathrm{OH}) \mathrm{Cl}$ ). These results show that besides the changes described above for the major mineral phases, also the total content and the leaching behavior of toxic heavy metals were changed. The total content losses of $\mathrm{Pb}, \mathrm{Cd}, \mathrm{Zn}, \mathrm{Ni}$ and $\mathrm{Cu}$ were about 91, 97, 40, 18 and 20\%, respectively, and the leaching release of all these metals were well below the regulatory thresholds for hazardous waste landfills. Regarding $\mathrm{Cr}$ the observed behavior is different. Indeed, whereas it was not volatilized during calcination at $1100{ }^{\circ} \mathrm{C}$, the amount released by leaching increased strongly, becoming a potential problematic element. This behavior has been reported in the literature, and the most likely reason is the formation of $\mathrm{CaCrO}_{4}$ at high temperatures, whose phase is leachable in water (Kirk et al., 2002; Wang et al., 2002).

It is important to notice that the APC residues when analyzed through STA, Fig. 3, by increasing the temperature from 20 to $1200{ }^{\circ} \mathrm{C}$, in a rate of $10{ }^{\circ} \mathrm{C} / \mathrm{min}$, a loss of $32.2 \%$ was detected. The significant loss observed when temperature is in the range of $600-750{ }^{\circ} \mathrm{C}$ is mainly due to the decomposition of $\mathrm{Ca}(\mathrm{OH}) \mathrm{Cl}(\mathrm{s})$ to $\mathrm{CaO}(\mathrm{s})$ and $\mathrm{HCl}(\mathrm{g})$ and $\mathrm{CaCO} 3(\mathrm{~s})$ to $\mathrm{CaO}(\mathrm{s})$ and $\mathrm{CO}_{2}(\mathrm{~g})$ (Quina et al., 2008b). For higher temperatures than $750{ }^{\circ} \mathrm{C}$ the weight loss is most likely related with the partial decomposition of the $\mathrm{NaCl}$ and $\mathrm{KCl}$ phases, with the release of $\mathrm{HCl}$ gas. The endothermic behavior of the clay and the mixture (clay $+5 \% \mathrm{APC}$ ) for a temperature higher than $1000{ }^{\circ} \mathrm{C}$ correspond to the sintering of the body.

Some heating microscope images of cubic APC residues samples, during sintering at a heating rate of $10{ }^{\circ} \mathrm{C} / \mathrm{min}$ are shown in Fig. 6 . The reduction of the sample dimensions during the sintering process can be noticed, by comparing the images from 40 to $1415{ }^{\circ} \mathrm{C}$. Indeed, during this heating process the sample kept the cubic shape up to $1415^{\circ} \mathrm{C}$. At $1474{ }^{\circ} \mathrm{C}$ the sample melted, and by increasing the temperature further, the glassy phases become softer and the viscosity significantly decreases.

Table 5

Total content (TC), and extracted amounts in the elutes by washing process.

\begin{tabular}{|c|c|c|c|c|c|c|c|c|c|c|c|c|c|c|}
\hline \multirow[t]{2}{*}{ Test } & $\mathrm{Pb}$ & $\mathrm{Cd}$ & $\mathrm{Zn}$ & $\mathrm{Cr}$ & $\mathrm{Ni}$ & $\mathrm{Cu}$ & $\mathrm{K}$ & $\mathrm{Na}$ & $\mathrm{Ca}$ & $\mathrm{Cl}$ & $\mathrm{SO}_{4}$ & $\mathrm{Si}$ & $\mathrm{Al}$ & $\mathrm{Fe}$ \\
\hline & \multicolumn{6}{|c|}{$(\mathrm{mg} / \mathrm{kg})$} & \multicolumn{8}{|c|}{$(\mathrm{g} / \mathrm{kg})$} \\
\hline TC & 2020 & 64 & 4308 & 232 & 121 & 456 & 26.7 & 27.6 & 299 & nd & nd & 65.9 & 39.1 & 16.1 \\
\hline A2W_10 min & 408 & $<\mathrm{DL}$ & 51 & 3.5 & 0.09 & 4.2 & 21.9 & 20.1 & 104 & 101.1 & 12.4 & nd & nd & nd \\
\hline A2W_24 h_1ext & 355 & $<\mathrm{DL}$ & 28 & 6.9 & 0.09 & 1.4 & 25.4 & 21.8 & 95.2 & 108.5 & 13.4 & $<\mathrm{DL}$ & $<\mathrm{DL}$ & $<\mathrm{DL}$ \\
\hline A2W_24 h_2ext & 130 & $<\mathrm{DL}$ & 18 & 9.0 & 0.1 & 0.05 & 6.2 & 5.6 & 25.5 & nd & nd & nd & nd & nd \\
\hline A2W_PO 4 & 18 & $<\mathrm{DL}$ & 1.5 & 5.1 & $<\mathrm{DL}$ & 0.23 & 25.6 & 20.9 & 66.6 & nd & nd & nd & nd & nd \\
\hline
\end{tabular}

$\mathrm{DL}$ - detection limit of FAAS; nd - not determined. 


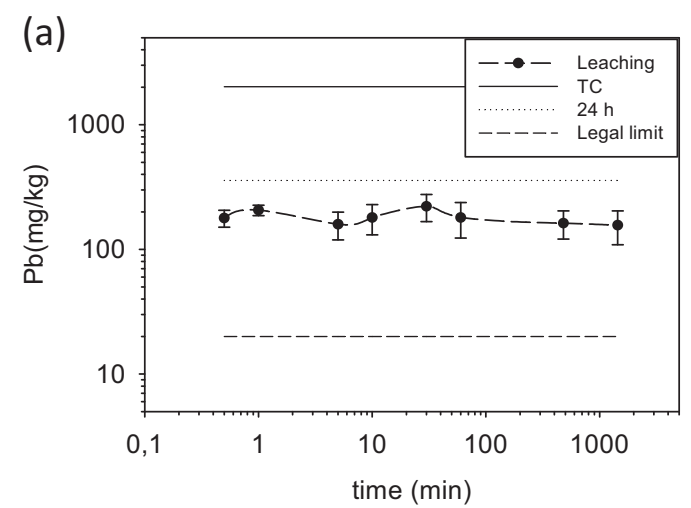

(b)

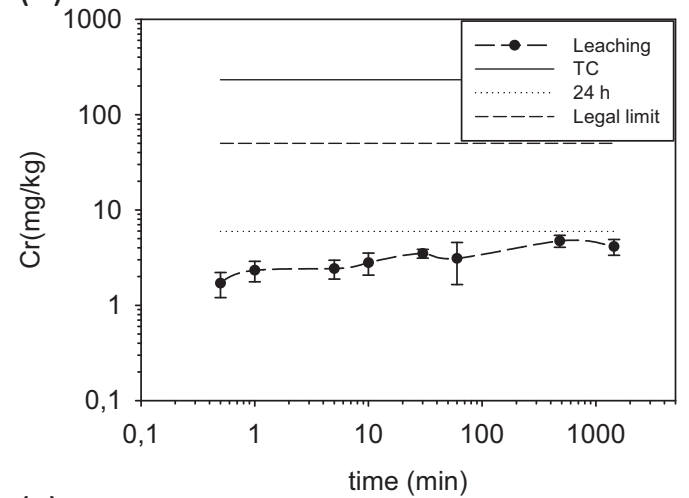

(c)

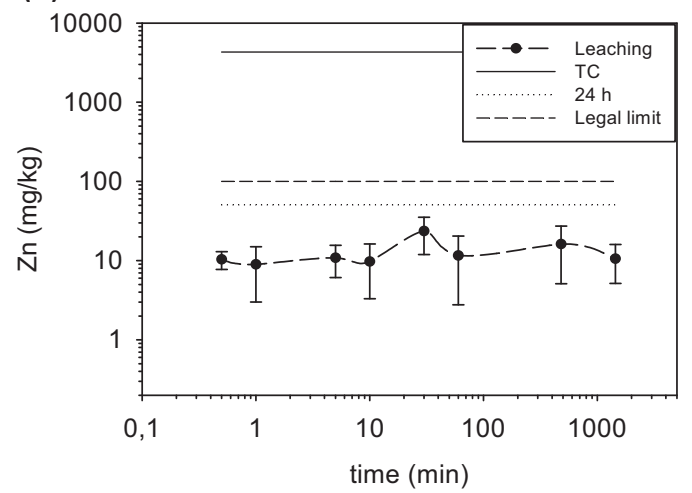

Fig. 7. Released amounts of (a) $\mathrm{Pb}$, (b) $\mathrm{Cr}$, and (c) $\mathrm{Zn}$ as a function of the time of the extraction from $0.5 \mathrm{~min}$ to $24 \mathrm{~h}$.

As previously referred by taking into account the Riley diagram, Fig. 1, no evidence of the bloating process was observed in this case.

As aforementioned, the washing of APC residues can be regarded as a first step of other possible treatments or recycling of the waste as a valuable material (Mangialardi, 2001; Nzihou and Sharrock, 2002;
Sabbas et al., 2003). This process entails the extraction of solid particles with a liquid phase aiming to improve the technological properties of the residue. The results obtained in these washing tests showed that some elements may be released in water in high quantities. Table 5 summarizes some data measured in the eluates obtained after $10 \mathrm{~min}$ (A2W_10 min) and $24 \mathrm{~h}$ (A2W_24 h_1ext) of washing, after a second extraction with $24 \mathrm{~h}$ (A2W_24 h_2ext), and after washing the waste with phosphoric acid $\left(\mathrm{A} 2 \mathrm{~W} \_\mathrm{PO}_{4}\right)$.

In general, the kinetic of washing is fast. After only 10 min of extraction, some elements were released in water in high quantities (for example $\mathrm{K}^{+}, \mathrm{Na}^{+}, \mathrm{Cl}^{-}$and $\mathrm{SO}_{4}^{2-}$ ), whereas for elements such as $\mathrm{Pb}, \mathrm{Zn}, \mathrm{Cr}$, Ni and $\mathrm{Cu}$ much lower quantities were extracted when compared to TC, and others ( $\mathrm{Cd}, \mathrm{Si}, \mathrm{Al}$ and $\mathrm{Fe}$ ) were below the detection limit (DL).

By using phosphoric acid in the washing procedure, a positive effect in heavy metals $(\mathrm{Pb}, \mathrm{Zn}, \mathrm{Ni}$ and $\mathrm{Cu}$ ) was observed, while for other elements (e.g. K, Na) a minor effect was detected.

In order to follow the kinetic of releasing of $\mathrm{Pb}$ and $\mathrm{Cr}$, dynamic leaching processes were conducted, and the results plotted in Fig. 7, where the TC for each element, the regulatory limit for hazardous landfills and the values obtained by performing a washing process within $24 \mathrm{~h}$ were also included. From Fig. 7a it can be observed that the legal limit for $\mathrm{Pb}$ is always largely exceeded; the first sample was taken at $0.5 \mathrm{~min}$ and also in this case the $\mathrm{Pb}$ concentration goes beyond the limit. The amount of $\mathrm{Cr}$ shows a slightly increase over time, and the regulatory limit can be surpassed after $60 \mathrm{~min}$, Fig. 7b. The leaching behavior of $\mathrm{Zn}$ is shown in Fig. 7c, and in this case higher variability is detected between replicates. However, the legal limit was never exceeded.

According to the overall data, the washing process should be performed at $\mathrm{L} / \mathrm{S} 10$, over $10 \mathrm{~min}$, at room temperature, using a small amount of phosphoric acid (adding at least $0.06 \mathrm{~mL} / \mathrm{g}$ of APC residues). By analyzing a sample of washed APC residues by XRD, the disappearance of the peaks corresponding to $\mathrm{NaCl}, \mathrm{KCl}$ and $\mathrm{CaClOH}$ was observed (Quina et al., 2008b). It is significant to note that for sample A2 during the washing process the mass loss was about $22 \%$ due to solubilization. Moreover, by heating the washed residue until $1200{ }^{\circ} \mathrm{C}$ an additional loss of $22 \%$ was further observed (Quina et al., 2008b), leading to a significant global loss of mass.

\subsection{Lightweight aggregates}

In the previous sections, it was shown that the clay has characteristics of bloating, whereas the APC residues has high fluxing components (near to 52\%) and low silicon oxide content. Thus, aiming to produce LWA, it is expectable that low percentages of incorporation will be feasible, and in this section this aspect will be explored.

In general, some conditions were required for producing bloating materials (de' Gennaro et al., 2004). Namely, the material must yield a high temperature glassy phase with appropriate viscosity to trap the gases; some chemical reactions must occur, releasing gas at the same time that the glassy phase was formed; and in the cooling phase an external glassy shell must be formed. The gases produced may comprise $\mathrm{CO}_{2}, \mathrm{CO}, \mathrm{H}_{2} \mathrm{O}, \mathrm{O}_{2}, \mathrm{SO}_{2}$, $\mathrm{HF}$ and $\mathrm{HCl}$, among others, and can be generated

Table 6

Probable chemical reactions releasing gases during the firing bloating process of LWA.

\begin{tabular}{|c|c|c|c|c|}
\hline & Reaction & Eq. & $\mathrm{T}\left({ }^{\circ} \mathrm{C}\right)$ & Ref. \\
\hline Organic matter & $\mathrm{C}_{\mathrm{org}}+\mathrm{O}_{2}(\mathrm{~g}) \rightarrow \mathrm{CO}_{2}(\mathrm{~g})+\mathrm{CO}(\mathrm{g})$ & $(1)$ & & Büchner et al. (1989) \\
\hline Calcium sulfate & $2 \mathrm{CaSO}_{4}(\mathrm{~s}) \rightarrow 2 \mathrm{CaO}(\mathrm{s})+2 \mathrm{SO}_{2}(\mathrm{~g})+\mathrm{O}_{2}(\mathrm{~g})$ & (2) & $1200-1350$ & Garea et al. (2003) \\
\hline Calcite & $\mathrm{CaCO}_{3}(\mathrm{~s}) \rightarrow \mathrm{CaO}(\mathrm{s})+\mathrm{CO}_{2}(\mathrm{~g})$ & (3) & $600-850$ & Garea et al. (2003) \\
\hline \multirow[t]{5}{*}{ Iron oxides } & $6 \mathrm{Fe}_{2} \mathrm{O}_{3}(\mathrm{~s}) \rightarrow 4 \mathrm{Fe}_{3} \mathrm{O}_{4}(\mathrm{~s})+\mathrm{O}_{2}(\mathrm{~g})$ & (4) & $>1150$ & Büchner et al. (1989) \\
\hline & $\mathrm{Fe}_{2} \mathrm{O}_{3}(\mathrm{~s})+\mathrm{C}(\mathrm{s}) \rightarrow 2 \mathrm{FeO}(\mathrm{s})+\mathrm{CO}(\mathrm{g})$ & (5) & 1100 & \\
\hline & $\mathrm{Fe}_{2} \mathrm{O}_{3}(\mathrm{~s})+\mathrm{CO}(\mathrm{g}) \rightarrow 2 \mathrm{FeO}(\mathrm{s})+\mathrm{CO}_{2}(\mathrm{~g})$ & (6) & & \\
\hline & $4 \mathrm{FeO}(\mathrm{s})+4 \mathrm{Al}_{2} \mathrm{O}_{3}(\mathrm{~s}) \rightarrow 4 \mathrm{FeAl}_{2} \mathrm{O}_{4}(\mathrm{~s})$ & (7) & & \\
\hline & $2 \mathrm{Fe}_{2} \mathrm{O}_{3}(\mathrm{~s})+\mathrm{C}+4 \mathrm{Al}_{2} \mathrm{O}_{3} \rightarrow 4 \mathrm{FeAl}_{2} \mathrm{O}_{4}+\mathrm{CO}_{2}(\mathrm{~g})$ & $(8)$ & & \\
\hline Portlandite & $\mathrm{Ca}(\mathrm{OH})_{2}(\mathrm{~s}) \rightarrow \mathrm{CaO}(\mathrm{s})+\mathrm{H}_{2} \mathrm{O}(\mathrm{g})$ & (9) & $350-450$ & Garea et al. (2003) \\
\hline Calcium hydroxychloride & $\mathrm{Ca}(\mathrm{OH}) \mathrm{Cl}(\mathrm{s}) \rightarrow \mathrm{CaO}(\mathrm{s})+\mathrm{HCl}(\mathrm{g})$ & (10) & $465-600$ & Bodénan and Deniard (2003) \\
\hline
\end{tabular}



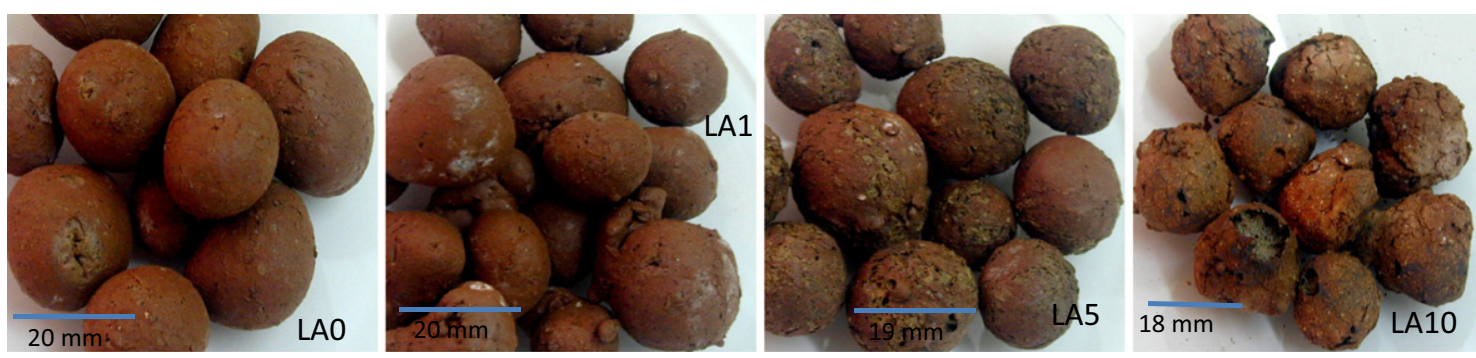

Fig. 8. Lightweight aggregates for $0,1,5$ and $10 \%$ of incorporation.

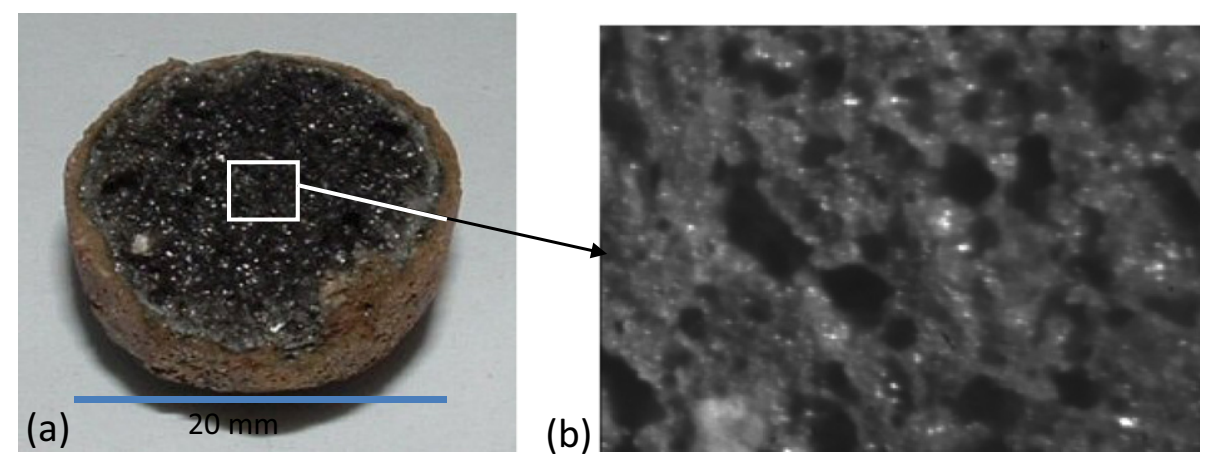

Fig. 9. Broken lightweight aggregates of type LAO (a) and a zoom of the internal core (b).

from the clay minerals phases, from some additives used for this purpose (e.g. oil) and also from thermal unstable phases from APC residues. Table 6 summarizes some of the many reactions that may be involved.

The recipes tested in these preliminary tests follows the industrial one, where clay, water and oil were mixed into a paste (blank: LA0), granulated into particles round in shape. After firing, the LWA obtained are indicated in Fig. 8 for 0, 1, 5 and 10\% of incorporation; Fig. 9a-b show a broken aggregate and a zoom of the interior region, respectively. The external appearance of LWA produced in a laboratorial furnace with $0 \%$ (LA0), 1\% (LA1), 5\% (LA5), and 10\% (LA10) of APC residues shows that when $5 \%$ and $10 \%$ of APC residues are used, the external glassy shell loses the smooth surface. These irregularities suggest a possible extra gas release during the firing process, due to the presence of the APC residues, which have the tendency to lose weight within the temperature range used, as previously shown in Fig. 3. Based on the morphology observed in Fig. 8, it is clear that incorporating $10 \%$ of APC residues is excessively detrimental to produce LWA. Therefore, the technological properties in this preliminary assessment were only determined for formulations LA0, LA1 and LA5, as indicate in Table 7. These results point out that if $5 \%$ of APC residues were incorporated, significant differences in bulk density and mechanical strength were observed. Thus, further studies should be conducted in order to maximize the percentage of incorporation and minimize the consequence in the technological properties. It is important to notice that since the washing treatment revealed that a reduction in the fluxing content is possible to achieve (see Fig. 1), additional studies should consider the possibility of incorporating pre-washed APC residues instead of as received from the incineration plant.

Table 7

Bulk and particle densities and mechanical strength of the lightweight aggregates.

\begin{tabular}{llll}
\hline Formulation & $\begin{array}{l}\text { Bulk density } \\
(\mathrm{g} / \mathrm{L})\end{array}$ & $\begin{array}{l}\text { Particle density } \\
(\mathrm{g} / \mathrm{mL})\end{array}$ & $\begin{array}{l}\text { Mechanical strength } \\
(\mathrm{MPa})\end{array}$ \\
\hline LA0 & 264 & 0.6 & 0.40 \\
LA1 & 279 & 0.6 & 0.46 \\
LA5 & 178 & 0.5 & 0.19 \\
\hline
\end{tabular}

Finally, it is essential to evaluate the environmental impact; in particular, the risks imposed on the surroundings by a recycling strategy must be weighed against creating new pollution sources elsewhere. In this scope, it is important to take into account the specific application under consideration. In the case of LWA the most probable uses are in cement bound products, but its direct contact with water is also possible for example for agricultural utilizations. Nonetheless, in the literature it is referred that the "end of life" condition, in particular when the material becomes debris, should be taken into account (van der Sloot et al., 2001). Therefore, the leaching behavior of LWA was evaluated after size reduction $(<1 \mathrm{~mm})$ of the LWA to simulate the worst scenario. Table 8 shows the leaching results obtained for formulations LA0, LA1 and LA5, according to the standards DIN 38414-S4 and TCLP. The main conclusion that can be drawn from these results is that all the measured quantities are well below the regulatory limits for considering the material as hazardous. However, when $5 \%$ of APC residues are used (LA5), the release of some species increases slightly $\left(\mathrm{Zn}, \mathrm{Cu}^{-\mathrm{Cl}^{-}}\right.$and $\left.\mathrm{SO}_{4}^{2-}\right)$. By comparing the results obtained through TCLP and DIN tests it can be seen that in general the releases are higher for the former case, which is due to the fact that the leaching solution has lower $\mathrm{pH}$, and then is more aggressive for the extraction processes. It is very important to note that low leaching values of the product do not necessarily indicate chemical immobilization of the pollutants in the ceramic matrix; indeed, this may indicate that pollutants of concern volatilize during sintering. Therefore, in future work the gaseous emissions should be analyzed in what concerns the most problematic elements (chlorides, volatile and semi-volatile metals).

\section{Conclusions}

This study aimed to characterize the natural industrial clay and APC residues from MSW incineration in order to evaluate the possibility of producing LWA with the commercial technological properties and simultaneously recycling the waste.

The results obtained for both materials showed that the bloating capacity, based on the chemical composition of silica, alumina and fluxing contents (Riley diagram), is significant for clay but null for APC 
Table 8

Results from leaching tests DIN 38414-S4 and TCLP for formulations LA0, LA1 and LA5

\begin{tabular}{|c|c|c|c|c|c|c|c|c|c|c|c|c|c|c|c|c|c|c|}
\hline & \multicolumn{2}{|l|}{$\mathrm{Pb}(\mu \mathrm{g} / \mathrm{L})$} & \multicolumn{2}{|c|}{$\mathrm{Cr}(\mu \mathrm{g} / \mathrm{L})$} & \multicolumn{2}{|l|}{$\mathrm{Cd}(\mu \mathrm{g} / \mathrm{L})$} & \multicolumn{2}{|c|}{$\mathrm{Zn}(\mathrm{mg} / \mathrm{L})$} & \multicolumn{2}{|c|}{$\mathrm{Ni}(\mathrm{mg} / \mathrm{L})$} & \multicolumn{2}{|c|}{$\mathrm{Cu}(\mathrm{mg} / \mathrm{L})$} & \multicolumn{2}{|c|}{$\mathrm{Cl}^{-}(\mathrm{mg} / \mathrm{L})$} & \multicolumn{2}{|c|}{$\mathrm{SO}_{4}^{2-}(\mathrm{mg} / \mathrm{L})$} & \multicolumn{2}{|c|}{$\mathrm{F}^{-}(\mathrm{mg} / \mathrm{L})$} \\
\hline & DIN & TCLP & DIN & TCLP & DIN & TCLP & DIN & TCLP & DIN & TCLP & DIN & TCLP & DIN & TCLP & DIN & TCLP & DIN & TCLP \\
\hline LAO & 4.25 & 7.52 & 0.82 & 8.62 & 0.028 & 0.256 & $<\mathrm{DL}$ & 0.037 & $<\mathrm{DL}$ & 0.024 & $<\mathrm{DL}$ & 0.085 & 0.14 & $\mathrm{nq}$ & 5.11 & $\mathrm{nq}$ & 0.76 & 1.89 \\
\hline LA1 & 0.72 & 6.67 & 0.78 & 7.87 & 0.003 & 0.397 & $<\mathrm{DL}$ & 0.027 & $<\mathrm{DL}$ & 0.042 & $<\mathrm{DL}$ & 0.065 & 0.84 & $\mathrm{nq}$ & 4.73 & $\mathrm{nq}$ & 0.67 & 1.77 \\
\hline LA5 & 3.42 & 13.3 & 1.44 & 7.83 & 0.051 & 0.446 & $<\mathrm{DL}$ & 0.067 & $<\mathrm{DL}$ & 0.044 & $<\mathrm{DL}$ & 0.170 & 3.24 & $\mathrm{nq}$ & 14.8 & $\mathrm{nq}$ & 0.57 & 0.77 \\
\hline $\mathrm{RL}^{\mathrm{a}}$ & 2000 & 5000 & 500 & nd & 1000 & 1000 & 10 & nd & 2 & nd & 10 & nd & 10000 & nd & 5000 & nd & 50 & nd \\
\hline
\end{tabular}

nd - not defined; nq - not quantified.

a $\mathrm{RL}$ - regulatory limit.

residues. The heating microscope images corroborate completely this behavior. The main crystalline phases of clay are quartz $\left(\mathrm{SiO}_{2}\right)$ and illite $\left(\left(\mathrm{K}, \mathrm{H}_{3} \mathrm{O}\right)(\mathrm{Al}, \mathrm{Mg}, \mathrm{Fe})_{2}(\mathrm{Si}, \mathrm{Al})_{4} \mathrm{O}_{10}\right)$, hematite $\left(\mathrm{Fe}_{2} \mathrm{O}_{3}\right)$, smectite $\left(\left(\mathrm{Na}, \mathrm{Ca}_{0.5}\right)\right.$ $\left.0.3\left((\mathrm{Al}, \mathrm{Fe}, \mathrm{Mg})_{2}(\mathrm{Si}, \mathrm{Al})_{4} \mathrm{O}_{10}\right)(\mathrm{OH})_{2} \cdot \mathrm{nH}_{2} \mathrm{O}\right)$, kaolinite $\left(\mathrm{Al}_{4} \mathrm{Si}_{4} \mathrm{O}_{10}(\mathrm{OH})_{8}\right)$ and traces of feldspar $\left((\mathrm{Na}, \mathrm{K}) \mathrm{AlSi}_{3} \mathrm{O}_{8}\right)$ and calcite $\left(\mathrm{CaCO}_{3}\right)$. Whereas the main crystalline phases of APC residues are halite $(\mathrm{NaCl})$, sylvite $(\mathrm{KCl})$, calcite $\left(\mathrm{CaCO}_{3}\right)$, anhydrite $\left(\mathrm{CaSO}_{4}\right)$, quartz $\left(\mathrm{SiO}_{2}\right)$, gehlenite $\left(\mathrm{Ca}_{2} \mathrm{Al}\left(\mathrm{AlSiO}_{7}\right)\right)$, hematite $\left(\mathrm{Fe}_{2} \mathrm{O}_{3}\right)$, portlandite $\left(\mathrm{Ca}(\mathrm{OH})_{2}\right)$ and calcium hydroxychloride $(\mathrm{Ca}(\mathrm{OH}) \mathrm{Cl})$. The thermogravimetry revealed that a total weight loss of $8.6 \%$ was observed for clay, while APC residues lost $32 \%$ when temperature rose to $1200{ }^{\circ} \mathrm{C}$.

The washing treatment for removing soluble salts has a fast kinetic (only $10 \mathrm{~min}$ is enough to solubilize $22 \%$ ), and a weight loss of $22 \%$ was observed by increasing temperature to $1200{ }^{\circ} \mathrm{C}$. Globally, the washing treatment could be beneficial in the scope of producing LWA and thus it will be further explored.

The preliminary tests involving LWA showed that incorporating $10 \%$ is excessively detrimental (the external glassy shell lose the smooth surface) and even $5 \%$ led to significant differences in bulk density and mechanical strength when compared with the reference case. The leaching experiments conducted to very low releasing amounts for both standards tested.

In summary, the main findings pointed out that the integration of the APC residues for producing LWA does not improve technological properties, but incorporations lower than $5 \%$ will be further tested.

\section{Acknowledgments}

Maxit-Argilas Expandidas SA (Avelar) is acknowledged for providing the clay used in the study. Valorsul, in particular the Central de Tratamento de Resíduos Sólidos Urbanos (incinerator plant) is also acknowledged for providing APC residues used in this research.

\section{References}

Bodénan, F., Deniard, P., 2003. Characterization of flue gas cleaning residues from European solid waste incinerators: assessment of various Ca-based sorbent processes. Chemosphere 51, 335-347.

Büchner, W., Schliebs, R., Winter, G., Buchel, K.H., 1989. Industrial Inorganic Chemistry. VCH, New York, USA.

Chandler, A.J., Eighmy, T.T., Hartlén, O., Kosson, D., Sawell, S.E., van der Sloot, H., Vehlow, J. IAWG - International Ash Working Group, 1997. Municipal solid waste incinerato residues. Studies in Environmental Science vol. 67. Elsevier Science, Amsterdam.

Chandra, S., Berntsson, L., 2002. Lightweight Aggregate Concrete: Science, Technology and Applications. William Andrew Publishing/Noyes Publications, New York.

Cheeseman, C.R., Virdi, G.S., 2005. Properties and microstructure of lightweight aggregate produced from sintered sewage sludge ash. Resour. Conserv. Recycl. 45, 18-30.

Cheeseman, C.R., Makinde, A., Bethanis, S., 2005. Properties of lightweight aggregate produced by rapid sintering of incinerator bottom ash. Resour. Conserv. Recycl. 43 , 147-162.

Chen, H.-J., Wang, S.-Y., Tang, C.-W., 2010. Reuse of incineration fly ashes and reaction ashes for manufacturing lightweight aggregate. Constr. Build. Mater. 24, 46-55.

Chen, H.-J., Yang, M.-D., Tang, C.-W., Wang, S.-Y., 2012. Producing synthetic lightweight aggregates from reservoir sediments. Constr. Build. Mater. 28, 387-394.

Chiou, I.-J., Wang, K.-S., Chen, C.-H., Lin, Y.-T., 2006. Lightweight aggregate made from sewage sludge and incinerated ash. Waste Manag. 26, 1453-1461.

de' Gennaro, R., Cappelletti, P., Cerri, G., de' Gennaro, M., Dondi, M., Langella, A., 2004. Zeolitic tuffs as raw materials for lightweight aggregates. Appl. Clay Sci. 25, 71-81. de' Gennaro, R., Cappelletti, P., Cerri, G., de' Gennaro, M., Dondi, M., Langella, A., 2005. Neapolitan yellow tuff as raw material for lightweight aggregates in lightweight structural concrete production. Appl. Clay Sci. 28, 309-319.

Dimech, C., Cheeseman, C.R., Cook, S., Simon, J., Boccaccini, A.R., 2008. Production of sintered materials from air pollution control residues from waste incineration. J. Mater. Sci. 43, 4143-4151.

Ducman, V., Mladenovic, A., Suput, J.S., 2002. Lightweight aggregate based on waste glass and its alkali-silica reactivity. Cem. Concr. Res. 32, 223-226.

Ferreira, C., Ribeiro, A., Ottosen, L., 2003. Possible applications for municipal solid waste fly ash. J. Hazard. Mater. 96, 201-216.

Garea, A., Marqués, J., Irabien, A., Kavouras, A., Krammer, G., 2003. Sorbent behavior in urban waste incineration: acid gas removal and thermogravimetric characterization. Thermochim. Acta 397, 227-236.

Gonzalez-Corrochano, B., Alonso-Azcarate, J., Rodas, M., 2009. Characterization of lightweight aggregates manufactured from washing aggregate sludge and fly ash. Resour. Conserv. Recycl. 53, 571-581.

Gonzalez-Corrochano, B., Alonso-Azcarate, J., Rodas, M., 2012. Effect of thermal treatment on the retention of chemical elements in the structure of lightweight aggregates manufactured from contaminated mine soil and fly ash. Constr. Build. Mater. 35, 497-507.

Haiying, Z., Youcai, Z., Jingyu, Q., 2011. Utilization of municipal solid waste incineration (MSWI) fly ash in ceramic brick: product characterization and environmental toxicity. Waste Manag. 31, 331-341.

Huang, S.-C., Chang, F.-C., Lo, S.-L., Lee, M.-Y., Wang, C.-F., Lin, J.-D., 2007. Production of lightweight aggregates from mining residues, heavy metal sludge, and incinerator fly ash. J. Hazard. Mater. 144, 52-58.

Hwang, C.-L., Bui, L.A., Lin, K.-L., Lo, C.-T., 2012. Manufacture and performance of lightweight aggregate from municipal solid waste incinerator fly ash and reservoir sediment for self-consolidating lightweight concrete. Cem. Concr. Compos. 34, $1159-1166$

Kirk, D.W., Chan, C.C.Y., Marsh, H., 2002. Chromium behavior during thermal treatment of MSW fly ash. J. Hazard. Mater. 90, 39-49.

Konta, J., 1995. Clay and man: clay raw materials in the service of man. Appl. Clay Sci. 10, 275-335.

Kourti, I., Cheeseman, C.R., 2010. Properties and microstructure of lightweight aggregate produced from lignite coal fly ash and recycled glass. Resour. Conserv. Recycl. 54, 769-775.

Latosinska, J., Zygadlo, M., 2011. The application of sewage sludge as an expanding agent in the production of lightweight expanded clay aggregate mass. Environ. Technol. 32, $1471-1478$

Mangialardi, T., 2001. Sintering of MSW fly ash for reuse as a concrete aggregate. J. Hazard. Mater. 87, 225-239.

Nzihou, A., Sharrock, P., 2002. Calcium phosphate stabilization of fly ash with chloride extraction. Waste Manag. 22, 235-239.

Qiao, X.C., Ng, B.R., Tyrer, M., Poon, C.S., Cheeseman, C.R., 2008. Production of lightweight concrete using incinerator bottom ash. Constr. Build. Mater. 22, 473-480.

Quina, M.J., Quinta-Ferreira, R.M., 2002. Properties of a recent hazardous waste in Portugal. Adv. Mater. Forum I Key Eng. Mater. 230-232, 400-403.

Quina, M.J., Almeida, M.A., Santos, R., Bordado, J.C., Quinta-Ferreira, R.M., 2006. Prediction of solid waste incineration residues quantity for valorization in lightweight aggregates. Adv. Mater. Forum III 2 Mater. Sci. Forum 1731-1735.

Quina, M.J., Bordado, J.C., Quinta-Ferreira, R.M., 2008a. Treatment and use of air pollution control residues from MSW incineration: an overview. Waste Manag. 28, 2097-2121.

Quina, M.J., Santos, R.C., Bordado, J.C., Quinta-Ferreira, R.M., 2008b. Characterization of air pollution control residues produced in a municipal solid waste incinerator in Portugal. J. Hazard. Mater. 152, 853-869.

Quina, M.J., Bordado, J.C., Quinta-Ferreira, R.M., 2009. The influence of $\mathrm{pH}$ on the leaching behaviour of inorganic components from municipal solid waste incineration APC residues. Waste Manag. 29, 2483-2493.

Quina, M.J., Bordado, J.C., Quinta-Ferreira, R.M., 2010. Chemical stabilisation of air pollution control residues from municipal solid waste incineration. J. Hazard. Mater. 179, 382-392.

Quina, M.J. Bordado, J.C., Quinta-Ferreira, R.M., 2011a. Percolation and batch leaching tests to assess release of inorganic pollutants from municipal solid waste incinerator residues. Waste Manag. 31, 236-245.

Quina, M.J., Bordado, J.C., Quinta-Ferreira, R.M., 2011b. Environmental impact of APC residues from municipal solid waste incineration: Reuse assessment based on soil and surface water protection criteria. Waste Manag. 31, 1984-1991. 
Riley, C.H., 1951. Relation of chemical properties to the bloating of clay. J. Am. Ceram. Soc. 34, 121-128.

Sabbas, T., Polettini, A., Pomi, R., Astrup, T., Hjelmar, O., Mostbauer, P., Cappai, G., Magel, G., Salhofer, S., Speiser, C., Heuss-Assbichler, S., Klein, R., Lechber, P., 2003. Management of municipal solid waste incineration residues. Waste Manag. 23, 61-88.

Sakai, S., Hiraoka, M., 2000. Municipal solid waste incinerator residue recycling by thermal processes. Waste Manag. 20, 249-258.

Tan, W.-F., Wang, L., Huang, C., Liu, Y.Y., Green, J.E., Newport, D., Green, T., 2012. Utilization of municipal solid waste incineration fly ash in lightweight aggregates. J. Cent. S. Univ. Technol. 19, 835-841.

Tettamanti, M., Collina, E., Lasagni, M., Pitea, D., Grasso, D., La Rosa, C., 1998. Characterization of fly ash from municipal solid waste incinerators using differential scanning calorimetry. Thermochim. Acta 321, 133-141.
Valle-Zermeño, R., Formosa, J., Chimenos, J.M., Martínez, M., Fernández, A.I., 2013. Aggregate material formulated with MSWI bottom ash and APC fly ash for use as secondary building material. Waste Manag. 33, 621-627.

van der Sloot, H.A., Hoede, D., Cresswell, D.J.F., Barton, J.R., 2001. Leaching behaviour of synthetic aggregates. Waste Manag. 21, 221-228.

Wainwright, P.J., Cresswell, D.J.F., 2001. Synthetic aggregates from combustion ashes using an innovative rotary kiln. Waste Manag. 21, 241-246.

Wang, K.-S., Chiang, K.-Y., Perng, J.-K., Sun, C.-J., 1998. The characteristics study on sintering of municipal solid waste incinerator ashes. J. Hazard. Mater. 59, 201-219.

Wang, K.-S., Sun, C.-J., Yeh, C.-C., 2002. The thermotreatment of MSW incinerator fly ash for use as an aggregate: a study of the characteristics of size-fractioning. Resour. Conserv. Recycl. 35, 177-190. 